\title{
ANALISIS PENYALAHGUNAAN IZIN KEIMIGRASIAN OVERSTAY OLEH WARGA NEGARA ASING DI MAKASSAR
}

\author{
Analysis of the Abuse of Overstay Immigration Permit by Foreigners in Makassar \\ Abdul Naim ${ }^{1}$, Ruslan Renggong ${ }^{2}$, Abd Salam Siku \\ ${ }^{1}$ Magister Ilmu Hukum Program Pascasarjana, Universitas Bosowa \\ ${ }^{2}$ Program Studi Ilmu Hukum, Program Pascasarjana, Universitas Bosowa \\ Email: abdulnaim@gmail.com \\ Diterima: 03 Januari 2021 \\ Dipublikasikan: 07 Juni 0221
}

\begin{abstract}
ABSTRAK
Penelitian ini bertujuan untuk mengetahui Sejauhmanakah penegakan hukum atas penyalahgunaan izin keimigrasian Overstay bagi orang asing di kota Makassar dan faktor-faktor yang mempengaruhi proses penegakan hukum penyalahgunaan izin keimigrasian Overstay bagi orang asing di Kota Makassar. Metode pengumpulan Data melalui Metode Penelitian Pustaka (Library Research) dan Metode Penelitian Lapangan (Field Research). Teknis Analisis secara kuantitatif dan kualitatif kemudian disajikan secara deskriptif yaitu menjelaskan, menguraikan dan menggambarkan sesuai dengan permasalahan, Penindakan dilakukan kepada WNA dengan memberikan pengenaan biaya beban atau deportasi.Kantor Imigrasi Kelas I Makassar bekerja sama dengan instansi terkait seperti Kepolisian, beserta jajarannya dan partisipasi masyarakat serta aktifnya penjamin dalam mempertanggung jawabkan keberadaan dan kegiatan Warga Negara Asing (WNA). Faktor Penghambatnya adalah jarak tempuh yang sangat jauh untuk menjangkau seluruh wilayah kerja kantor Imigrasi Kelas I Makassar dan jumlah tim penegak hukum di kantor Imigrasi Kelas I Makassar yang kurang memadai.
\end{abstract}

Kata Kunci: Penyalahgunaan, Izin Tinggal, Overstay, Warga Negara Asing

\section{ABSTRACT}

This study aims to determine the extent of law enforcement for the abuse of Overstay immigration permit for foreigners in the city of Makassar and the factors that influence the law enforcement process of the abuse of Overstay immigration permit for foreigners in Makassar City. Data collection methods are through Library Research and Field Research Methods. Technical analysis is quantitative and qualitative then presented descriptively, such as explaining, elaborating and describing based on the problem. Treatment is given to foreigners by imposing charges or deportation. The supporting factor is Immigration Office Class I Makassar in collaboration with related agencies such as the Police, along with its staff and community participation and the active guarantors in being accountable for the existence and activities of foreigners (WNA). The inhibiting factors are the very long distance to reach the entire working area of Immigration Office Class I Makassar and insufficient number of law enforcement teams at Immigration Office Class I Makassar.

Keywords: Abuse, Residence Permit, Overstay, Foreigners

\section{PENDAHULUAN}

Hukum dalam keimigrasian merupakan bagian dari substansi Hukum Administrasi Negara yang mempunyai fungsi sebagai penyelenggara administrasi negara atau penyelenggara administrasi pemerintahan (Santoso, 2004). Fungsi keimigrasian yang diatur dalam UndangUndang Nomor 6 Tahun 2011 tentang Keimigrasian (selajutnya disebut UU Keimigrasian) bertujuan untuk melaksanakan dan menetapkan kebijakan di bidang keimigrasian (Gintin., dkk, 2004). Salah satu instrument konkrit pelayanan keimigrasian terhadap orang asing adalah suatu izin keimigrasian. Izin keimigrasian terhadap orang asing dalam bentuk visa maupun penerapan tanda masuk di Tempat Pemeriksaan Imigrasi merupakan legalitas izin orang asing di wilayah Indonesia.

Berdasarkan Undang-Undang Keimigrasian, izin tinggal diberikan kepada orang asing sesuai dengan visa yang dimilikinya. Izin tinggal keimigrasian terdiri atas 5 jenis yaitu : Pertama, izin tinggal diplomatik diberikan kepada orang asing yang masuk wilayah Indonesia dengan visa diplomatik, Kedua, izin tinggal dinas diberikan kepada orang asing yang masuk wilayah Indonesia dengan visa dinas, Ketiga, izin tinggal kunjungan, diberikan kepada orang asing yang masuk wilayah Indonesia dengan visa kunjungan atau Keempat, izin tinggal terbatas diberikan kepada orang asing yang masuk wilayah Indonesia dengan visa tinggal terbatas, anak yang baru lahir di wilayah Indonesia dan pada saat lahir ayah dan/atau ibunya pemegang izin tinggal kunjungan. Kelima, izin tinggal tetap diberikan kepada orang asing pemegang izin tinggal terbatas yang telah 5 tahun berturut-turut di wilayah Indonesia. Pada kenyataannya, izin tinggal keimigrasian sering disalahgunakan orang asing di Indonesia.

Pengawasan orang asing tidak hanya dilakukan pada saat mereka masuk, tetapi juga selama mereka berada di Wilayah Indonesia, termasuk kegiatannya, Pengawasan Keimigrasian mencakup penegakan hukum Keimigrasian, baik yang bersifat administratif maupun tindak pidana 
Keimigrasian. Keimigrasian menjalankan tugas dan wewenang secara khusus berdasarkan Undang-Undang ini. Oleh karena itu, perlu pula diatur PPNS Keimigrasian. Dalam aspek pelayanan pengawasan tidak pula terlepas dari kondisi geografis Wilayah Indonesia yang mana terdiri Pulau-pulau, yang mempunyai jarak yang dekat, Bahkan perbatasan langsung dengan negara tetangga, yang pelaksanaan Fungsi Keimigrasian di sepanjang garis perbatasan merupakan kewenangan instansi imigrasi .

Undang-undang No.6 Tahun 2011 Tentang Keimigrasian dan tindak pidana keimigrasian, dalam suatu perspektif keimigrasian setiap orang dianggap telah melewati garis wilayah perbatasan teritorial ketika telah melewati pemeriksaan keimigrasian untukmemproses pendaratan bagi setiap pelintas baik masuk maupun keluar. Pelabuhan udara atau pelabuhan laut secara fisik kedua titik tersebut berada di dalam garis wilayah batas teritorial suatu negara dan merupakan bagian dari wilayah darat atau wilayah perairan pedalaman yang sepenuhnya bagian dari suatu yuridiksi Negara.

Berdasarkan kebijakan selektif (selective policy) yang menjunjung tinggi nilai hak asasi manusia, perlu diatur masuknya Orang Asing ke dalam suatu Wilayah Indonesia, demikian pula dalam bagi Orang Asing yang memperoleh Izin Tinggal dalam Wilayah Indonesia harus sesuai dengan maksud dan tujuannya berada di Indonesia. Berdasarkankebijakan dimaksud serta dalam rangka melindungi kepentingan nasional, hanya Orang Asing yang memberikan manfaat serta tidak membahayakan keamanan dan ketertiban umum diperbolehkan masuk dan beradadi Wilayah Indonesia.

Sepanjang tahun 2018 ada 82 warga negara asing dari berbagai negara yang bekerja diberbagai bidang di Kota Makassar, seperti bidangbidang industri, perumahan, restoran, dan pengolahan. Sementara itu,Kepala Bidang Penempatan dan Perluasan Kesempatan Kerja Disnaker Kota Makassar, Andi Rahmat Mappatoba mencatat, sejak 2016-2018 sedikitnya ada 150 orang Tenaga Kerja Asing (TKA) diberbagai negara bekerja di perusahaan atau industri Kota Makassar. Ratusan TKA yang masuk mengisi lapangan pekerjaan dengan bekerja sebagai chef di hotel.

Sepanjang tahun 2019 saja, sudah ada Warga negara asing yang menyalahgunakan izin tinggalnya di Kota Makassar. Tentu saja hal tersebut berdampak pada Penyalahgunaan izin tinggal atau overstay juga dianggap karena pihak ke imigrasian belum adanya suatu tindakan yang tegas atas permasalahan tersebut. Masihada kendala dalam pengawasan dan menindak pelanggaran Izin Tinggal terbatas yang dilakukan warga negara asing.

\section{METODE}

Penelitian Penelitian ini dilakukan pada KantorImigrasi Makassar. Data yang diperoleh melalui kegiatan penelitian sehingga dapat dianalisis secara kuantitatif dan kualitatif kemudian disajikan secara deskriptif yaitu menjelaskan, menguraikan dan menggambarkan sesuai dengan permasalahan yang tidak erat kaitannya dengan oleh penulis penelitian yang dilakukan.Teknik pengumpulan data dalam penelitian ini adalah dengan cara mempergunakan beberapa cara antara lain.

a. Metode Penelitian Pustaka (Library Research)

Penelitian pustaka tidak dilaksanakan untuk mengumpulkan sejumlah data, meliputi suatu bahan pustaka yang bersumber dari buku-buku, dan dokumendokumen serta peraturan-peraturan yang berhubungan dengan penelitian ini.

b. Metode Penelitian Lapangan (Field Research)

Penelitian dalam suatu lapangan penulis memperoleh data Primer dengan menggunakan metode wawancara (interview), sehubungan dengan pihak-pihak yang dapat memberikan informasi yang berkaitan dengan judul yang ditulis.

\section{HASIL DAN PEMBAHASAN}

Penegakan Hukum Atas Penyalahgunaan izin Keimigrasian Overstay Bagi Orang Asing Di Kota Makassar

Penegakan hukum dalam penyalahgunaan izin keimigrasian Overstay bagi orang negara Asing (WNA) yang khususnya di Kota Makassar, menurut Bapak Syiradjuddin Kepala Sub Seksi Intelijen Keimigrasian Kantor Imigrasi Makassar, menyatakan bahwa dalam pelaksanaan tugas keimigrasian, keseluruhan aturan hukum keimigrasian itu ditegakkan kepada setiap orang yang berada diwilayah Indonesia apa lagi bagi Orang Asing di Kota Makassar.

1. Pengawasan Penyalahgunaan izin Keimigrasian Overstay Bagi Orang Asing Di kota Makassar

Pengawasan dalam penindakan keimigrasian terhadap orang asing merupakan suatu upaya dalam pemerintah yang tidak sekaligus merupakan ruang lingkup keimigrasian utuk menciptakan suatu keamanan dan ketertiban umum secara garis besar fungsi pengawasan dalam penindakan orang asing dirumuskan dalam 3 (tiga) fungsi imigrasi yaitu sebagai aparatur pelayanan masyarakat dalam pengamanan suatu Negara, penegakan hukum keimigrasian dan fasilitator ekonomi nasionall.

Menurut Syiradjuddin, selaku Kepala Subseksi Intelijen Keimigrasian Kanim mengatakan bahwa :"Pengawasan yang dapat dilakukan pertama kali saat masuk dan keluar suatu wilayah Indonesia diantaranya mengajukan permohonan visa orang asing diawasi tujuannya, lalu dikirim ke Kedutaan Besar Negara yang bersangkutan lalu diambil, di Bandar udara dilakukan pemeriksaan ulang kelengkapan administrasi di Tempat Pemeriksaan Imigrasi (TPI) hingga sampai di suatu tempat wilayah dimana pemeriksaan lebih mendalam pada administrasi namun secara kesisteman langsung ke lapangan" (wawancara, 20 November 2020).

Sehingga orang asing dalam berlaku tertib selama berada di di Indonesia dilakukan pengawasan oleh Pemerintah melalui Dirjen Imigrasi Kementerian Hukum dan HAM, secara garis besarnya dalam pengawasan 
terhadap orang asing di Indonesia meliputi dua hal yaitu masuk dan keluarnya orang asing ke dan dari wilayah Indonesia dan keberadaan suatu serta kegiatan orang asing di wilayah Indonesia khusus di wilayah Indonesia

Pengawasan dalam orang asing dilakukan pemerintah dalam bentuk dan cara sebagai berikut:

a. Pengumpulan suatu pengolahan data orang asing yang masuk atau keluar wilayah Indonesia ;

b. Pendaftaran sehingga orang asing yang berada di wilayah Indonesia;

c. Pemantauan, pengumpulan, dan pengolahan bahan keterangan dan informasi mengenai kegiatan orang asing;

d. Penyusunan daftar nama-nama orang asing yang tidak dikehendaki masuk atau keluar wilayah Indonesia dan kegiatan lainnya.

Penegakan hukum pengawasan di Kantor Imigrasi dilaksanakan oleh seksi Intelijen dan Penindakan. Pengawasan warga negara asing di Indonesia baik izin kunjungan tinggal sementara maupun izin tinggal menetap, Pengawasan orang asing dilakukan untuk mengawasi kegiatan orang asing yang tinggal di wilayah Pasal 66 ayat (2) Undang-Undang Nomor 6 Tahun 2011, pengawasan Keimigrasian meliputi:

a. Pengawasan terhadap warga Negara Indonesia yang memohon dokumen perjalanan, keluar atau masuk Wilayah Indonesia dan yang berada di luar Wilayah Indonesia; dan atau masuk Wilayah Indonesia dan yang berada di luar Wilayah Indonesia;

b. Serta pengawasan terhadap keberadaan dan kegiatan orang asing di Wilayah Indonesia, Pengawasan terhadap lalu lintas orang asing yang masuk atau keluar wilayah Indonesia.

Dimana pengawasan yang dilakukan saat orang asing mengajukan permohonan pembuatan visa di Kedutaan Republik Indonesia di luar negeri, setelah dikabulkan permohonannya, pengawasan selanjutnya yaitu memeriksa kelengkapan administrasi seperti paspor dan visa di Tempat Pemeriksaan Imigrasi (TPI) yang ada di di Bandar udara atau pelabuhan.

Apabila Orang Asing dalam melakukan suatu pelanggaran maka seksi penindakan Kantor Imigrasi berperan sesuai dalam Pasal 74 Undang-Undang Nomor 6 Tahun 2011 tentang Intelijen Keimigrasian.

Dalam suatu rangka melaksanakan suatu fungsi Intelijen Keimigrasian dalam Pejabat Imigrasi melakukan suatu penyelidikan Keimigrasian dan pengamanan Keimigrasian serta berwenang;

a. Mendapatkan suatu keterangan sehingga masyarakat atau instansi pemerintah;

b. Mendatangi tempat atau bangunan yang dapat diduga sehingga ditemukan dan keterangan dan kegiatan orang asing;

c. Melakukan suatu operasi intelijen keimigrasian; atau

d. Melakukan dalam pengamanan terhadap data dan informasi keimigrasian dalam informasi keimigrasiaan serta pengamanan pelaksanaan tugas keimigrasiaan.
Dengan pernyataan Sirajudin Kepala Subseksi Intelijen Keimigrasian Kanim di Kantor Imigrasi Kelas 1 Makassar dalam Tindakan pengawasan kelengkapan administrasi orang asing yang selalu masuk dalam wilayah Indonesia telah sesuai dalam Pasal 68 UndangUndang Nomor 6 Tahun 2011. Pengawasan dalam keimigrasian terhadap orang asing yang dilakukan dengan cara pengumpulan, pengolahan, serta penyajian data dan informasi, penyusunan dalam daftar nama orang asing yang dikenai dalam penangkalan atau pencegahan, pengawasan terhadap suatu keberadaan dan kegiatan orang asing di Wilayah Indoensia, pengambilan suatu foto dan sidik jari dan kegiatan lain yang dapat dipertanggungjawabkan dalam Pasal 68, Undang-Undang Nomor 6 Tahun 2011. Pengawasan yang tidak dilakukan untuk memastikan bahwa nama orang asing yang ada di wilayah Indoensia tidak ada dalam daftar pencegahan dan penangkalan.

Apabila dalam pengawasan ditemukan pelanggaran keimigrasian seperti penyalahgunaan izin tinggal maka izin tinggal telah habis (Overstay) dan tidak memiliki izin tinggal (illegal stay), maka yang dapat dilakukan suatu tindakan keimigrasian diantaranya tindakan administrasi dan projustitia.

Menurut Muliati, bahwa "Pelanggaran terdapat masalah izin tinggal yang telah habis (Overstay) ditindak secara administratif. Sehingga Pelanggaran yang dapat ditindak secara administratif yaitu jika di Indonesia terdapat propaganda seperti ISIS (Islamic State Iran Syria). Tindakan administratif seperti dalam deportasi diberikan kepada propaganda karena lebih cepat dari tindakan pro justitia, apabila keberadaan propaganda lebih lama di Indonesia akan membahayakan keamanan Negara" (wawancara, 22 November 2020).

Sejalan dengan pernyataan Muliati selaku Seksi Penindakan Keimigrasian, tindakan administratif yang merupakan dan diberikan kepada orang asing yang melanggar izin dan tempat tinggal telah sesuai dengan Pasal 78 Undang - Undang Nomor 6 Tahun 2011 yang berbunyi :

a. Orang Asing dalam pemegang Izin Tinggal yang telah berakhir masa berlakunya sehingga masih berada dalam suatu wilayah Indonesia kurang dari 60 (enam puluh) hari dari suatu batas waktu Izin tinggal dikenai biaya beban sesuai dengan ketentuan peraturan perundang-undangan;

b. Orang Asing yang tidak membayar biaya dalam beban sebagaimana dalam ayat (1) dikenai Tindakan Administratif Keimigrasian berupa deportasi dan penangkalan;

c. Orang Asing dapat pemegang Izin tinggal yang telah berakhir masa berlakunya sehingga masih berada dalam suatu wilayah Indonesia lebih dari 60 (enam Puluh) hari dari batas waktu izin tinggal dikenai tindakan administratif Keimigrasian berupa Deportasi dan penangkalan.

Dengan suatu penegakan hukum sehingga Warga Negara Asing (WNA) di Kota Makassar telah sesuai 
dengan Undang-undang Nomor 6 Tahun 2011 Tentang Keimigrasian.

2. Tindakan Administratif Terhadap Warga Negara Asing (WNA) Yang Melanggar Izin Tinggal (Overstay)

Orang asing yang selalu berada dalam wilayah Indonesia sehingga melakukan suatu kegiatan berbahaya atau patut diduga akan berbahaya bagi keamanan dan ketertiban umum dan tidak menghormati atau mentaati peraturan Perundang-undangan yang berlaku. Pemerintah dapat melakukan tindakan keimigrasian yang berupa ;

a. Pembatasan dalam perubahan atau pembatalan izin keberadaan;

b. Larangan suatu keberadaan di suatu atau beberapa tempat tertentu di wilayah Indonesia;

c. Keharusan dalam suatu tempat tinggal di suatu tempat tertentu di wilayah Indonesia;

d. Pengusiran suatu deportasi suatu wilayah Indonesia atau penolakan masuk ke wilayah Indonesia.

Tindakan suatu administratif dibagi dalam beberapa jenis diantaranya pencantuman dalam daftar pencegahan atau pembatalan izin tinggal, larangan suatu keberadaan di satu atau beberapa tempat tertentu di wilayah Indonesia, keharusan untuk bertempat tinggal di suatu tempat tertentu di wilayah Indonesia, Pengenaan Biaya beban dan deportasi dari wilayah Indonesia (Pasal 75 Ayat (2) Undang-Undang Nomor 6 Tahun 2011).

Dalam,Pasal 75 ayat 1 tentang tindakan administratif yang berbunyi pejabat suatu imigrasi berwenang melakukan suatu tindakan administratif keimigrasiaan terhadap orang asing yang berada suatu wilayah Indonesia yang melakukan kegiatan berbahaya dan patut diduga membahayakan keamanan dan ketertiban umum atau tidak menaati peraturan perundang-undangan.

Agar Indonesia tetap aman dan tentram dalam pengawasan orang asing di suatu wilayah Indonesia, sehingga pengawasan terhadap orang asing yang masuk, keberadaan, kegiatan dan keluar dari suatu wilayah Indonesia Antara lain dapat menimbulkan 2 (dua) kemungkinan yakni :

Pertama; orang asing mentaati peraturan yang berlaku dan tidak melakukan kegiatan yang berbahaya bagi keamanan dan ketertiban umum, hal ini tidak menimbulkan masalah keimigrasian maupun kenegaraan. Kedua; Orang asing tidak mentaati peraturan perundangundangan yang berlaku di Indonesia, hal ini menimbulkan masalah dan dapat dikenankan tindakan hukum berupa :

a. Tindakan dalam Hukum Pidana suatu penyidikan keimigrasian yang merupakan bagian daripada rangkaian integrated Criminal Justice system, system dalam peradilan pidana (penyidikan, penuntutan, peradilan) contohnya penyelundupan narkoba, penyelundupan senjata api dan barangbarang terlarang lainnya; dan/atau.

b. Tindakan hukum administratif Negara merupakan tindakan administratif dalam bidang suatu keimigrasian di luar proses peradilan. Sehingga tindakan dalam keimigrasian ini adalah diantaranya deportasi sehingga orang asing untuk keluar dari wilayah yurisdiksi Negara kesatuan Republik Indonesia contohnya penyalahgunaan ijin tinggal keimgirasian, overstay, imigran gelap dan lain sebagainya.

Tabel 1. Daftar Over Stay (OS) Kantor Imigrasi Kelas I Makassar Tahun 2018

\begin{tabular}{|c|c|c|c|c|c|c|}
\hline No & Nama & $\begin{array}{l}\text { Jenis } \\
\text { Kelamin }\end{array}$ & Kebangsaan & No. Pasport & $\begin{array}{l}\text { Pemegang } \\
\text { Izin Tinggal }\end{array}$ & $\begin{array}{c}\text { Jumlah } \\
\text { OS } \\
\text { (Hari) } \\
\end{array}$ \\
\hline 1 & $\begin{array}{l}\text { Robina } \\
\text { paru }\end{array}$ & $\operatorname{Pr}$ & Malaysia & $\begin{array}{l}\text { K3486674 } \\
1\end{array}$ & ITAS & 5 \\
\hline 2 & Ze Tang & $\mathrm{Lk}$ & China & $\begin{array}{l}\text { E8669823 } \\
4\end{array}$ & VOA & 2 \\
\hline 3 & $\begin{array}{l}\text { Victor } \\
\text { Aditya } \\
\text { Dos } \\
\text { Remedios }\end{array}$ & $\mathrm{Lk}$ & $\begin{array}{l}\text { Timor } \\
\text { Leste }\end{array}$ & 0011829C & $\begin{array}{l}\text { Izin } \\
\text { Kunjungan }\end{array}$ & 6 \\
\hline 4 & $\begin{array}{l}\text { Horst } \\
\text { Hubertus } \\
\text { Liebner }\end{array}$ & Lk & Jerman & $\begin{array}{l}\text { C4JN2GY } \\
2 \mathrm{~V}\end{array}$ & ITAS & 16 \\
\hline 5 & $\begin{array}{l}\text { Audrey } \\
\text { Anna } \\
\text { Maria } \\
\text { Cayre }\end{array}$ & $\operatorname{Pr}$ & Perancis & $\begin{array}{l}13 \mathrm{BB} 6997 \\
5\end{array}$ & VOA & 2 \\
\hline 6 & $\begin{array}{l}\text { Benjamin } \\
\text { Didier } \\
\text { Maryconn } \\
\text { e Moyon }\end{array}$ & Lk & Perancis & $\begin{array}{l}\text { 17FC8761 } \\
2\end{array}$ & VOA & 2 \\
\hline 7 & $\begin{array}{l}\text { Allysa } \\
\text { Dewi }\end{array}$ & $\operatorname{Pr}$ & Malaysia & $\begin{array}{l}\text { H5099509 } \\
6\end{array}$ & BVKS & 3 \\
\hline 8 & $\begin{array}{l}\text { Sitti Aidah } \\
\text { Binti } \\
\text { Amirullah }\end{array}$ & $\operatorname{Pr}$ & Malaysia & $\begin{array}{l}\text { H5088318 } \\
3\end{array}$ & BVKS & 3 \\
\hline 9 & $\begin{array}{l}\text { Muhamma } \\
\text { d Fikri } \\
\text { Albukhari } \\
\text { Bin } \\
\text { Amirullah }\end{array}$ & $\mathrm{Lk}$ & Malaysia & $\begin{array}{l}\text { H5088318 } \\
5\end{array}$ & BVKS & 3 \\
\hline 10 & $\begin{array}{l}\text { Muhamma } \\
\text { d Asyari } \\
\text { Syafie } \\
\text { Amirullah }\end{array}$ & Lk & Malaysia & $\begin{array}{l}\text { H5088318 } \\
4\end{array}$ & BVKS & 3 \\
\hline
\end{tabular}

Berdasarkal tabel 1 menunjukkan daftar over stay Tahun 2018 sebanyak 10 Orang dari Laki-laki dan Perempuan, dari kebanggsaan Malaysia sebanyak 5 orang, Cina 1 orang, Timor Leste 1 orang, Jerman 1 orang dan, Prancis 2 orang yang melakukan pelanggaran Over Stay

Tabel 2. Daftar Over Stay (OS) Kantor Imigrasi Kelas I Makassar Tahun 2019

\begin{tabular}{|c|c|c|c|c|c|c|}
\hline No & Nama & $\begin{array}{l}\text { Jenis } \\
\text { Kelamin }\end{array}$ & Kebangsaan & $\begin{array}{l}\text { No. } \\
\text { Pasport }\end{array}$ & $\begin{array}{l}\text { Pemegang } \\
\text { Izin } \\
\text { Tinggal }\end{array}$ & $\begin{array}{l}\text { Jumlah } \\
\text { OS } \\
\text { (Hari) }\end{array}$ \\
\hline 1 & $\begin{array}{l}\text { Francois } \\
\text { Dirk } \\
\text { Taljaard }\end{array}$ & Lk & $\begin{array}{l}\text { Afrika } \\
\text { Selatan }\end{array}$ & $\begin{array}{l}\text { A0473553 } \\
5\end{array}$ & VOA & 7 \\
\hline 2 & $\begin{array}{l}\text { Maiana } \\
\text { Sacrament } \\
\text { o } \\
\text { Moreira }\end{array}$ & Pr & Brazil & YC240656 & VOA & 3 \\
\hline 3 & $\begin{array}{l}\text { Muhamma } \\
\text { d Ilyas } \\
\text { Nadeem }\end{array}$ & & Pakistan & $\begin{array}{l}\text { BC174541 } \\
3\end{array}$ & $\begin{array}{l}\text { Izin } \\
\text { kunjungan }\end{array}$ & 11 \\
\hline 4 & $\begin{array}{l}\text { Zulkifli } \\
\text { al-Amin } \\
\text { Lothian }\end{array}$ & Lk & Australia & N9347699 & ITAS & 7 \\
\hline
\end{tabular}




\begin{tabular}{lllll}
\hline 5 & $\begin{array}{l}\text { Ahmad Lk } \\
\text { Maulana }\end{array}$ & Australia & N9347637 ITAS & 7 \\
& $\begin{array}{l}\text { Lothian } \\
6\end{array}$ & $\begin{array}{l}\text { Park Lk } \\
\text { Jeongsu }\end{array}$ & Korea Selatan M6004701 Izin & 3 \\
7 & $\begin{array}{l}\text { Kunjungan } \\
\text { Patel Jinal Lk }\end{array}$ & P5982976 ITAP & 12 \\
& $\begin{array}{l}\text { Hashmukh } \\
\text { bhai }\end{array}$ & India & \\
\hline \multicolumn{7}{l}{ Sumber Data : Kantor Imigrasi Kelas I Makassar Tahun 2019 }
\end{tabular}

Berdasarkal Tabel 2 menunjukkan daftar over stay Tahun 2019 sebanyak 7 Orang dari Laki-laki dan Perempuan, dari kebangsaan Afrika Selatan 1 orang, Brazil 1 orang, Pakistan 1 orang, Australia 2 orang, Korea Selatan 1 orang dan India 1 orang yang melakukan pelanggaran Over Stay.

Tabel 3. Daftar Over Stay (OS) Kantor Imigrasi Kelas I Makassar Tahun 2020

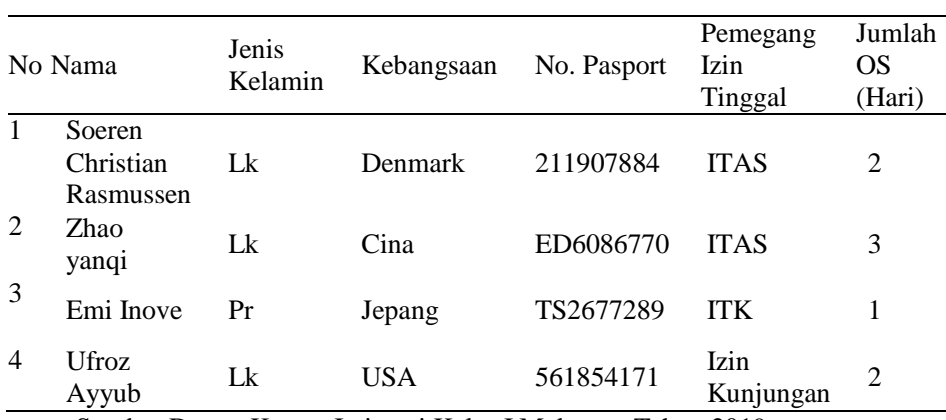

Sumber Data : Kantor Imigrasi Kelas I Makassar Tahun 2019

Berdasarkal tabel 3 menunjukkan daftar over stay Tahun 2020 sebanyak 4 Orang dari Laki-laki dan Perempuan, berkebangsaan Denmark 1 orang, China 1 orang, Jepang 1 orang, USA 1 orang yang melakukan pelanggaran Over Stay

Tindakan administratif dibagi menjadi beberapa jenis, diantaranya pencantuman pembatasan, perubahan atau pembatalan izin tinggal, larangan untuk berada di satu atau beberapa tempat tertentu di wilayah Indonesia sehingga keharusan untuk bertempat tinggal disuatu tempat suatu wilayah Indonesia, pengenaan biaya beban dan deportasi dari wilayah Indonesia (Pasal 75 ayat (2) Undang-Undang Nomor 6 Tahun 2011).

Pengenaan biaya beban disesuaikan dealam Pelanggaran yang dilakukan. dalam Pasal 78 ayat 1 menyebutkan setiap orang asing pemegang izin tinggal yang telah berakhir dimasa berlakunya dan masih berada dalam suatu wilayah Indonesia dan batas waktu izin tinggal dikenai biaya beban sesuai dengan ketentuan peraturan perundang-undangan dimana suatu batas waktu 60 (enam puluh) hari diberikan untuk tinggal di Indonesia dari batas waktu izin tinggal dikenai tindakan administratif keimigrasian berupa deportasi dan penangkalan.

Berdasarkan tabel tersebut, jumlah orang asing yang melanggar izin tinggal (Overstay) di Kota Makassar pada Januari sampai Maret Tahun 2019 sebanyak 4 orang dikenakan dalam sanksi adminstratif yakni membayar biaya beban dan sebanyak 4 Orang asing yang di deportasi.

Tabel 4. Jumlah Denda Overstay

\begin{tabular}{lll}
\hline No. & Periode & Jumlah (RP) \\
\hline 1. & Febbuari - Juni 2018 & Rp. 100.000.000 \\
2. & Januari - Desember & Rp. 130.000.000 \\
& 2019 & \\
3. & Januari - Maret 2020 & Rp. 150.000.000 \\
\hline
\end{tabular}

Sumber Data : Kantor Imigrasi Kelas I Makassar Tahun 2019

Jumlah denda dalam Overstay (PNBP) masuk dalam kekas Negara sehingga digunakan dalam melakukan pembangunan Negara, khususnya dalam pembangunan sarana dan prasarana sehingga pelayanan keimigrasian, pengawasan dan penegakan hukum yang menjadi fungsi imigrasi Indonesia, fasilitas makan serta transportasi bagi Petugas Pemeriksa Keimigrasian dan biaya pengawalan dari perwakilan Kantor Imigrasi terhadap Warga Negara Asing (WNA) yang dideportasi dari Indonesia.

Tabel 5. Data Penetapan Tindakan Administratif Keimigrasian

\begin{tabular}{|c|c|c|c|c|c|}
\hline $\mathrm{NO}$ & Jenis Pelanggaran & $\begin{array}{l}\text { Tahun } \\
2020\end{array}$ & $\begin{array}{l}\text { Tahun } \\
2019 \\
\end{array}$ & $\begin{array}{l}\text { Tahun } \\
2018\end{array}$ & $\begin{array}{l}\text { Juml } \\
\text { ah }\end{array}$ \\
\hline 1 & $\begin{array}{l}\text { Tidak Memiliki Izin } \\
\text { Tinggal }\end{array}$ & 1 & 4 & 6 & 11 \\
\hline 2 & Overstay & 4 & 7 & 10 & 21 \\
\hline 3. & $\begin{array}{l}\text { Telah Menyelesaikan } \\
\text { Masalah Pidana }\end{array}$ & 6 & - & - & 6 \\
\hline 4 & $\begin{array}{l}\text { Penyalahgunaan Izin } \\
\text { Tinggal }\end{array}$ & - & 12 & 7 & 19 \\
\hline 5 & $\begin{array}{l}\text { Illegal Entry Dan Illegal } \\
\text { Stay }\end{array}$ & - & - & 2 & 2 \\
\hline 6 & $\begin{array}{l}\text { Kewarganegaraan } \\
\text { Ganda }\end{array}$ & - & - & 1 & 1 \\
\hline & Jumlah & 11 & 23 & 26 & 60 \\
\hline
\end{tabular}

Sumber Data : Kantor Imigrasi Kelas I Makassar Tahun 2019

Berdasarkan Tabel 5 jumlah pelanggaran WNA di Indonesia dari tahun 2018 sampai dengan tahun 2020 sebanyak 60 jenis pelanggaran, namun pada tahun 2020 terjadi penurunan pelanggaran oleh WNA di Indonesia, hal ini disebabkan karena meningkatnya kasus penderita Covis-19 di Indonesia sehingga WNA yang melakukan pelanggaran overstay diberi keringanan berdasarkan kebijakan pemerintah.

3. Projustitia

Dalam Keputusan Menteri Kehakiman dan Hak Asasi Manusia No. M.04.PR.07.10 Tanggal 7 Desember Tahun 2005 tentang Organisasi dan Tata Kerja Departemen Kehakiman dan Hak Asasi Manusia Indonesia, tergambar bahwa Subdit Penyidikan berada dalam lingkungan Direktorat Jenderal Imigrasi. Dalam pelaksanaan tugas kepala seksi bertanggung jawab kepada Kepala Subdit Penyidikan Keimigrasian sedangkan Kepala Subdit penyidikan bertanggung jawab langsung kepada Direktur Penyidikan Keimigrasian yang memimpin Direktorat Penyidikan dan Penindakan Keimigrasian.

Table 6. Data Penyidikan Tindak Pidana Keimigrasian (Projustitia) Tahun 2018

\begin{tabular}{|c|c|c|c|c|}
\hline 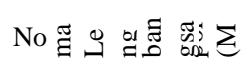 & $\begin{array}{l}\text { Pasal } \\
\text { yang }\end{array}$ & Status & $\begin{array}{l}\text { Putusan } \\
\text { Pengadi }\end{array}$ & Ket. \\
\hline
\end{tabular}




\begin{tabular}{|c|c|c|c|c|c|c|c|c|c|}
\hline & & & & $\begin{array}{l}\text { disan } \\
\text { gkaka } \\
\mathrm{n}\end{array}$ & $\begin{array}{l}\text { Peny } \\
\text { idika } \\
\mathrm{n}\end{array}$ & $\begin{array}{l}\text { Penu } \\
\text { ntuta } \\
\mathrm{n}\end{array}$ & $\begin{array}{l}\text { Peng } \\
\text { adila } \\
\mathrm{n}\end{array}$ & lan & \\
\hline 1 & $\begin{array}{l}\text { Zha } \\
\text { ng } \\
\text { Hec } \\
\text { hen } \\
\text { g }\end{array}$ & $\begin{array}{l}\mathrm{C} \\
\text { in } \\
\mathrm{a}\end{array}$ & - & $\begin{array}{l}\text { Pasal } \\
122 \\
\text { Huruf } \\
\text { (a) } \\
\text { UU } \\
\text { No. } \\
6 \\
\text { Tahun } \\
2011 \\
\text { tentan } \\
\text { g } \\
\text { Keimi } \\
\text { grasia } \\
\text { n }\end{array}$ & $\mathrm{Ya}$ & $\mathrm{Ya}$ & $\mathrm{Ya}$ & $\begin{array}{l}101 \\
\text { /Pid.Sus } \\
/ 2018 / \mathrm{P} \\
\mathrm{N} \\
\text { Snj.Penj } \\
\text { ara } 6 \\
\text { Bulan } \\
\text { dan } \\
\text { Denda } \\
\text { 200 Juta } \\
\text { Subsidi } \\
\text { er } 1 \\
\text { Bulan } \\
\text { Kurung } \\
\text { an. }\end{array}$ & $\begin{array}{l}\text { Tela } \\
\text { h } \\
\text { Dide } \\
\text { porta } \\
\text { si } \\
\text { Pada } \\
\text { Tang } \\
\text { gal } \\
06 \\
\text { Mei } \\
2019\end{array}$ \\
\hline
\end{tabular}

Sumber Data : Kantor Imigrasi Kelas I Makassar Tahun 2019

Berdasarkan Tabel 7 Dalam perkara Pelanggaran Undang-Undang Keimigrasian dengan pelaku bernama Zhang Hecheng, Penyidik Pegawai Negeri Sipil (PPNS) Keimigrasian mengetahui adanya pelanggaran dalam Undang-Undang Nomor 6 Tahun 2011 tentang Keimigrasian, pasal 122 Huruf (a) Tentang Keimigrasian berdasarkan laporan tersebut dari Putusan Pengadilan terhadap pelanggarannya Nomor :101/Pid.Sus/2018/PN Snj, dengan ancaman 6 Bulan Penjara dan Denda 200 Juta, Subsudier 1 Bulan Kurungan.

Sedangkan kewenangan Subdit Penyidikan Keimigrasian adalah berkaitan dengan penyiapan bahan penyusunan kebijakan, melakukan pembinaan dan bimbingan teknis di bidang penyidikan tindak pidana Penyidik Pegawai Negeri Sipil Keimigrasian.

Table 7. Data Penyidikan Tindak Pidana Keimigrasian (Projustitia) Tahun 2019

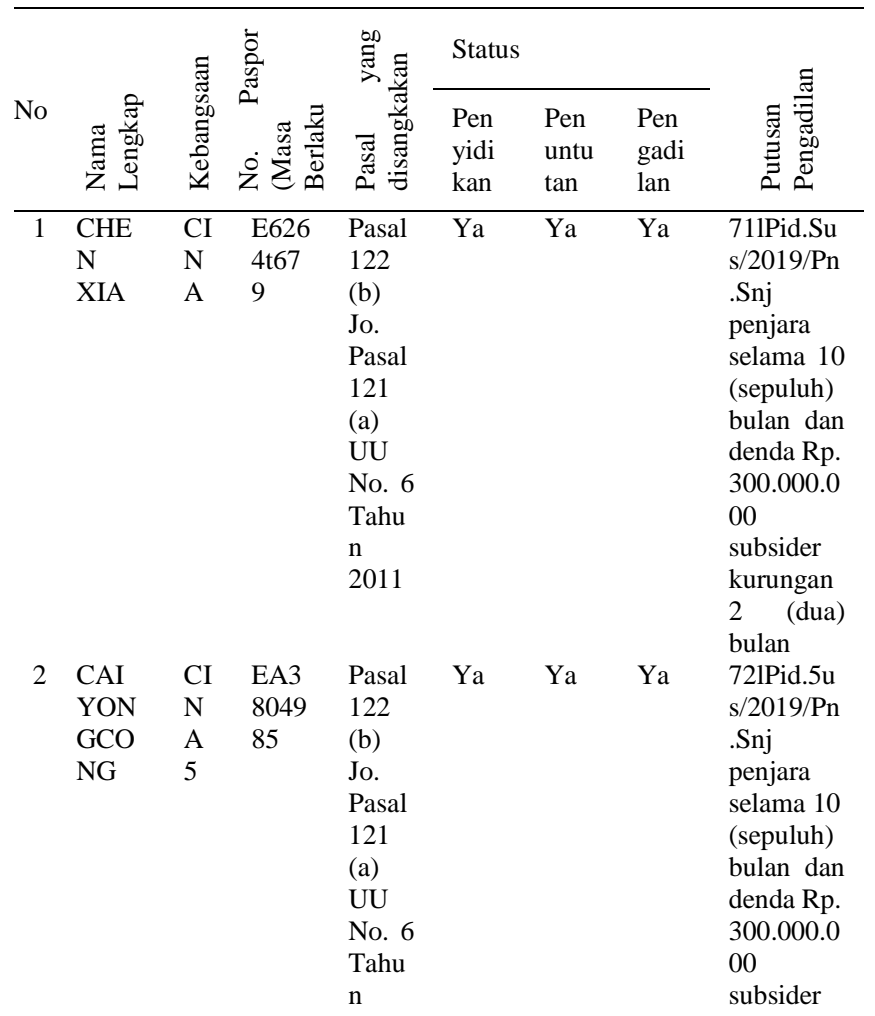

\begin{tabular}{|c|c|c|c|c|c|c|c|c|}
\hline & & & & 2011 & \multirow{17}{*}{ Ya } & \multirow{17}{*}{ Ya } & & \multirow{5}{*}{$\begin{array}{l}\text { kurungan } \\
2 \quad \text { (dua) } \\
\text { bulan }\end{array}$} \\
\hline & & & & Tenta & & & & \\
\hline & & & & & & & & \\
\hline & & & & Keim & & & & \\
\hline & & & & $\begin{array}{l}\text { igrasi } \\
\text { an }\end{array}$ & & & & \\
\hline & & CI & E2A & Pasal & & & $\mathrm{Ya}$ & 721Pid.Su \\
\hline & MIN & $\mathrm{N}$ & 9073 & 122 & & & & s/2019/P \\
\hline & HON & A & 26 & (a) & & & & N Slr \\
\hline & & & & UU & & & & Pidanasel \\
\hline & & & & No.5 & & & & ama6(ena \\
\hline & & & & Tahu & & & & m) \\
\hline & & & & $\mathrm{n}$ & & & & bulan \\
\hline & & & & 2011 & & & & denda \\
\hline & & & & Tenta & & & & sebesar \\
\hline & & & & ng & & & & Rp.5.000. \\
\hline & & & & Keim & & & & 000 \\
\hline & & & & igrasi & & & & subside \\
\hline & & & & an & & & & penjara \\
\hline
\end{tabular}

Sumber Data : Kantor Imigrasi Kelas I Makassar Tahun 2019

Berdasarkan Tabel 7, perkara pelanggaran UndangUndang Keimigrasian dengan pelaku bernama Chen Xia, Putusan Pengadilan terhadap pelanggarannya Nomor :71/Pid.Sus/2019/PN.Snj, dengan penjara selama 10 (sepuluh) bulan dan Denda Rp. 300.000.000 , Subsudier 2 (dua) Bulan Kurungan. Cai Yongcong, Putusan Pengadilan terhadap Pelanggaran Nomor :72/Pid.Sus/2019/PN.Snj, dengan penjara selama 10 (sepuluh) bulan dan Denda Rp. 300.000 .000 subsider kurungan 2 (dua) bulan. Dan Lai Minhong, Putusan Pengadilan terhadap Pelanggaran Nomor :72/Pid.Sus/2019/PN.Slr, dengan penjara selama 6 (enam) bulan dan Denda Rp. 5.000.000 subsider penjara.

Table 8. Data Penyidikan Tindak Pidana Keimigrasian (Projustitia) Tahun 2020

\begin{tabular}{|c|c|c|c|c|c|c|c|c|c|}
\hline & \multirow[b]{2}{*}{ 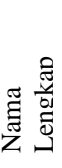 } & \multirow{2}{*}{ 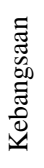 } & \multirow{2}{*}{ 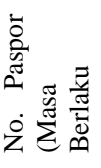 } & \multirow{2}{*}{$\begin{array}{l}\text { Pasal } \\
\text { yang } \\
\text { disan } \\
\text { gkak } \\
\text { an }\end{array}$} & \multicolumn{3}{|c|}{ Status } & \multirow{2}{*}{ 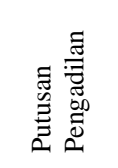 } & \multirow[b]{2}{*}{ Ket. } \\
\hline & & & & & $\begin{array}{l}\text { Pen } \\
\text { yidi } \\
\text { kan }\end{array}$ & $\begin{array}{l}\text { Pen } \\
\text { untu } \\
\text { tan }\end{array}$ & $\begin{array}{l}\text { Pen } \\
\text { gadi } \\
\text { lan }\end{array}$ & & \\
\hline \multirow[t]{15}{*}{1} & $\mathrm{Y}$ & CI & E10 & Pasal & $\mathrm{Ya}$ & $\mathrm{Ya}$ & $\mathrm{Ya}$ & Pidana & Tela \\
\hline & $\mathrm{u}$ & $\mathrm{N}$ & 458 & 122 & & & & Penjara 4 & $\mathrm{~h}$ \\
\hline & K & A & 671 & huruf & & & & Bulan, & men \\
\hline & $\mathrm{e}$ & & & (a) & & & & denda & jala \\
\hline & & & & UU & & & & 100 juta & ni \\
\hline & & & & No. & & & & subsider & mas \\
\hline & & & & 6 & & & & 1 bulan & $\mathrm{a}$ \\
\hline & & & & Tahu & & & & (550/pid. & taha \\
\hline & & & & $\mathrm{n}$ & & & & sus/2019 & nan \\
\hline & & & & 2011 & & & & /PN. & dan \\
\hline & & & & tenta & & & & Mks) & tela \\
\hline & & & & ng & & & & & $\mathrm{h}$ \\
\hline & & & & Keim & & & & & dide \\
\hline & & & & igrasi & & & & & port \\
\hline & & & & an & & & & & asi \\
\hline
\end{tabular}

Sumber Data : Kantor Imigrasi Kelas I Makassar Tahun 2019

Berdasarkan Tabel 8 Dalam perkara Pelanggaran Undang-Undang Keimigrasian dengan pelaku bernama $\mathrm{Yu}$ Ke, Penyidik Pegawai Negeri Sipil (PPNS) Keimigrasian mengetahui adanya pelanggaran dalam Undang-Undang Nomor 6 Tahun 2011 tentang Keimigrasian dalam pasal 122 Huruf (a) Tentang Keimigrasian berdasarkan laporan tersebut dari Putusan Pengadilan terhadap pelanggarannya Nomor :550/Pid.Sus/2019/PN.Mks, dengan ancaman 4 
(empat) Bulan Penjara dan Denda Rp. 100.000.000 , Subsudier 1 Bulan dan telah menjalani masa tahanan dan telah dideportasi.

Penyidik Pegawai Negeri Sipil (PPNS) dalam Keimigrasian mengetahui suatu pelanggaran UndangUndang Nomor 6 Tahun 2011, pasal 122 Huruf (a) Tentang Keimigrasian berdasarkan laporan tersebut kantor Imigrasi Kelas I Makassar melakukan Penegakan hukum Keimigrasian (Projustitia) terhadap satu warga Negara China yang telah melanggar Undang-Undang No. 6 Tahun 2011 Tentang Keimigrasian, disebutkan Setiap orang yang dengan sengaja menyalahgunakan atau melakukan kegiatan yang tidak sesuai dengan maksud dan tujuan pemberian izin Tinggal yang diberikan kepadanya.

Faktor - Faktor Yang Mempengaruhi Proses Hukum Penyalahgunaan Izin Keimigrasiaan Overstay Bagi Orang Asing Di Kota Makassar.

1. Faktor Internal yaitu;

a. Anggaran yang Terbatas;

Mengenai dana atau biaya operasional yang terbatas, anggaran menjadi hal klasik terhambatnya kinerja Imigrasian, dalam meningkatkan kinerja imigrasi dengan wilayah kerja yang sangat luas yakni 10 wilayah kabupaten dan 1 kotamadya sehingga harus membutuhkan anggaran yang tidak sedikit, mulai dari mengunjungi setiap kabupaten serta sarana dan prasarana Dalam penegak hukum/pejabat imigrasi dengan instansi terkait sehingga partisipasi dari masyarakat sehingga dapat meminimalkan angka pelanggaran administrasi keimigrasian di wilayah indonesia.

b. Sumber Daya Manusia (SDM)

Sumber daya manusia yang dimaksud ialah Pegawai yang bertugas di Keimigrasian Kelas I Makassar, salah satu aspek terpenting dari faktor pegawai adalah pengetahuan-pengetahuan pegawai akan bidang pekerjaan yang dilakukan. Pekerjaan dapat dilakukan oleh pegawai jika pegawai tersebut mempunyai pengetahuan tentang tugas dan fungsinya masing-masing. Selain pengetahuhan, kinerja suatu institusi ataupun kelembagaan juga dilihat dari jumlah pegawai yang akan menjalankan tugasnya mengingat Wilayah kerja Kantor Keimigrasian Kelas I Makassar yang sangat, kantor Imigrasi Makassar memiliki pegawai berjumlah 115 orang dengan tingkat pendidikan yang rata-rata telah sarjana dan mendapatkan SK-PK pendidik yang diberikan melalui pelatihan dari tingkat pusat yang nantinya akan mempermudah untuk melaksanakan tugas.

Tabel 9. Pegawai Kantor Keimigrasian Kelas I Makassar Tahun 2020

\begin{tabular}{llllll}
\hline \multirow{2}{*}{ Golongan } & \multicolumn{2}{l}{ Ruang } & & & \multirow{2}{*}{ Jumlah } \\
\cline { 2 - 5 } & A & B & C & D & \\
\hline IV & 4 & - & - & - & 4
\end{tabular}

\begin{tabular}{llllll} 
III & 20 & 30 & 30 & 17 & 97 \\
II & 14 & - & - & - & 14 \\
I & - & - & - & - & - \\
\hline Jumlah & 38 & 30 & 30 & 17 & 115 \\
\hline \multicolumn{5}{l}{ Sumber Data : Kantor Imigrasi Kelas I Makassar Tahun 2019 }
\end{tabular}

Berdasarkan Tabel 9 jumlah pegawai Keimigrasian Kelas I Makassar berjumlah 115 orang yang dimana berdasarkan kepangkatannya golongan IV A terdiri dari 4 orang, golongan III A 20 Orang, III B 30 orang, III C 30 orang, dan III D 17 orang sedangkan golongan III B terdiri dari 5 orang, golongan III C 9 Orang, dan II A 14 orang.

Dari data Jumlah Pagawai Keimigrasian Kelas I Makassar yang bertugas di Keimigrasian sebanyak 115 Orang dan sebagian sebagai Pegawai Imigrasi yang dibagian Teknis sebanyak 88 Orang, dan 6 Orang Sebagai Penyidik Pegawai Negeri Sipil Keimigrasian di kantor Imgrasi Kelas I Makassar.

Tabel 10. Data Pendidikan Pegawai Keimigrasian Kelas I Makassar

\begin{tabular}{l|l|l|l|l|l|l|l}
\hline \multirow{2}{*}{ Jenis Kelamin } & \multicolumn{7}{|c}{ Pendidikan } \\
\cline { 2 - 8 } & SD & SMP & SMA & D3 & SI & S2 & S3 \\
\hline Laki-laki & - & - & 10 & 3 & 30 & 8 & 2 \\
Perempuan & - & - & 8 & 3 & 14 & 5 & - \\
\hline Jumlah & - & - & 18 & 6 & 44 & 13 & 2 \\
\hline
\end{tabular}

Berdasarkan Tabel 10 data Pendidikan Keimigrasian Kelas I Makasar berjumlah 83 dari setiap golongan pendidikam berdasarkan pendidikan SMA 18 Orang, D3 6 Orang, SI 44 Orang, S2 13 Orang, S3 2 Orang.

Dari data Jumlah Pendidikan Pagawai Keimigrasian Kelas I Makassar yang bertugas di Keimigrasian sebanyak 83 sebagian sebagai data pendidikan Pegawai Imigrasi. Merupakan pelaksanaan teknis di kantor Keimigrasian.

Bahwa dalam kuantitas jumlah suatu tim Pengawasan dan penidakan di Kantor Imigrasi Kelas I Faktor penegak hukum yakni pihak-pihak yang tidak secara langsung berkecimpung dalam suatu bidang penegakan hukum, Sumber Daya Kantor Imigrasi Kelas I Makassar yang menjadi penegakan hukum yaitu pejabat imigrasi itu sendiri Sulawesi Selatan sehingga menyebabkan ketidak seimbangan dalam penegakan hukum, Manusia (SDM) karena banyaknya jumlah orang asing yang datang dalam suatu wilayah. Sehingga Makassar kurang memadai dan kurangnya.

Tim Pengawasan dan penindakan terkadang sedikit dapat terkendala karena dalam jumlah dari suatu Tim pengawsan dalam penindakan tidak seimbang dengan Jumlah warga Negara Asing (WNA) yang akan selalu datang di Wilayah Sulawesi Selatan Di Kota Makassar. Kantor Imigrasi Kelas I Makassar masih kurang memadai,

\section{Sarana dan Prasarana}

Dalam melakukan pengawasan terhadap warga negara asing, kantor Imigrasi Kelas I Makassar memiliki 2 kendaraan operasional yang digunakan, pengawasan itu dilakukan dengan cara mengunjungi langsung tempat atau 
perusahaan dimana warga negara asing tersebut bekerja atau menetap

1. Substansi Hukum;

Substansi hukum yang dimaksud adalah peraturan perundang-undangan yang mengatur tentang imigrasi. Berkaitan dengan Undnag-Undang Nomor 6 Tahun 2011 Tentang Imigrasi, masih relevan dengan perkembangan hukum dewasa ini masih relevan dengan perkembangan hukum dewasa ini masih relevan karena selain memberikan kebebasan setiap manusia untuk berkeluarga antar bangsa, mengembangkan diri dengan bebas menggunakan fasilitas keimigrasian juga tetap melindungi Hak Asasi Manusia baik itu Warga Negara Indonesia sendiri maupun Orang Asing yang berada di Indonesia.

2. Stuktur Hukum;

Struktur hukum yang dimaksud adalah berkaitan dengan pemerintah yang memiliki tugas, pokok dan fungsi penyelenggaraan Keimigrasian.

3. Budaya Hukum;

Budaya hukum yang dimaksud adalah berkaitan dengan budaya hukum masyarakat Indonesia dalam hal penyelenggaraan Keimigrasian. Bahwa, kesadaran hukum masyarakat Indonesia hukum oleh Warga Negara Indonesia karena ada keuntungan tanpa mempertimbangkan resiko terburuk yang akan dihadapi.

Dimana dalam Penegakan hukum berasal dalam masyarakat sehingga bertujuan dalam mencapai suatu kedamaian di dimana dalam Masyarakat sebagai lingkungan dimana hukum tersebut berlaku dan diterapkan dalam Masyarakat Dalam. Partisipasi dalam masyarakat yang aktif dalam suatu pengawasan terhadap orang asing di suatu wilayah Indonesia penegakan hukum sangat membantu dalam. Masyarakat sehingga melaporkan suatu keberadaan dan kegiatan orang asing sesuai PP 13 Tahun 2013 yang menyebutkan setiap orang yang memberikan dalam yang melaporkan PP 13 Tahun 2013 yang menyebutkan Atau Pejabat Pemerintah Daerah setempat dalam jangka waktu 24 (dua Puluh empat) jam sejenak tanggal kedatangan orang asing tersebut. Kesempatan orang asing menginap ditempat suatu kediamannya wajib melaporkan kepada Kantor Kepolisian Republik Indonesia

Pasal tersebut dikuatkan dengan pernyataan Muliati Seksi Penindakan Keimigrasian yang mengatakan bahwa :"Orang asing yang tinggal suatu daerah wilayah Indonesia, wajib melapor keberadaannya Kepada Ketua Rukun Tetangga (RT) atau Rukun Warga (RW) setempat, sehingga Ketua RT/RW keberadaan orang asing dapat dilaporkan kekantor ke kecamatan dan kelurahan. Agar tidak ada kekelurahan memberikan laporan ke Kantor Imigrasi yang berisikan identitas lengkap, nomor passport, nomor visa dan tujuannya datang ke Indonesia" . (wawancara, 22 Novemver 2020)

Selain dalam partisipasi suatu masyrakat ada partisipasi khusus yang sangat penting orang asing di wilayah Indonesia dalam keberadaan. Sponsor Sehingga penjamin dan adalah seseorang yang bertanggung jawab terhadap keberadaan dalam kegiatan orang asing asing Selama di Indonesia. Pasal 63 ayat (1) asing tertentu yang berada suatu Wilayah Indonesia wajib memiliki suatu penjamin yang menjamin keberadaannya yang menyebutkan orang. Melaporkan suatu perubahan status sipil, status keimigrasian dan perubahan alamat orang asing, penjamin juga dalam berkewajiban.

Pasal dapat diperkuat dengan pernyataan Muliati, Seksi Penindakan Keimigrasian (wawancara, 22 November 2020), yang menyatakan :"Penjamin harus aktif terhadap suatu keberadaan dalam kegiatan orang asing sehingga tidak melanggar izin tinggal (overstay)".

Dalam penegak hukum/pejabat imigrasi dengan instansi terkait sehingga partisipasi dalam masyarakat dapat meminimalkan angka pelanggaran suatu administrasi keimigrasian indonesia di wilayah.

Adapun Faktor kebudayaan yakni sebagai hasil karya, pada karsa manusia sehingga pergaulan hidup cipta dan rasa yang didasarkan. Tarik tersendiri sehingga kebudayaan masyarakat Indonesia yang ramah menyebabkan banyak wisatawan mancanegara yang datang di Indonesia, sehingga datang di Indonesia, dalam Kebudayaan Indonesia mempunyai suatu daya, Indonesia terdiri dalam berbagai suku bangsa terdapat bermacam ragam kebudayaannya sehingga bangunan rumah adat, batik, jepara ukuran, taria-tarian, upacara adat perkawinan dalam sikap masyarakat Indonesia yang terkenal ramah dalam masyarakat.

Pejabat Imigrasi di Kantor Kelas I Makassar telah sesuai dalam Undang-Undang Nomor 6 Tahun 2011tentang Keimigrasian dalam Pasal 66 ayat (2) dan melibatkan suatu instansi terkait dalam Kepolisian Indonesia. Pemerintah Kabupaten dan Kota dan Dinas Dalam Pengawasan yang dapat dilakukan suatu Pejabat Transmigrasi Kota Makassar serta partisipasi masyarakat Ketenagakerjaan, Pengawasan yang dapat dilakukan oleh pejabat imigrasi pada saat orang asing akan masuk dan keluar wilayah Indonesia.

\section{KESIMPULAN DAN SARAN}

Berdasarkan hasil penelitian ini dapat disimpulkan bahwa Penegakan dalam hukum terhadap kepada Orang Asing yang melanggar Izin tinggal (Overstay) di Kantor Imigrasi I Kelas Makassar telah sesuai sehingga dalam Undang-Undang yang mengatur mengenai keimigrasian yaitu Undang-Undang Nomor 6 Tahun 2011 dan Peraturan Pemerintah Nomor 31 Tahun 2013 Tentang Peraturan Pelaksanaan Undang-Undang Nomor 6 Tahun 2011. Penegakan hukum tidak terlaksanakan oleh bagian penegakan hukum di Kantor Imigrasi Kelas I Makassar saat ditemukan pelanggaran administratif Faktor-faktor dalam mempengaruhi penegakan hukum terhadap WNA di Kota Makassar yaitu adanya faktor Internal dan Faktor Eksternal, faktor internal yaitu masih terbatasnya pegawai Kantor Imigrasi Kelas I Makassar yang telah mendapat pelatihan sebagai Penyidik Pegawai Negeri Sipil 
Keimigrasian, masih terbatasnya sarana dan prasarana untuk mendukung pelaksanaan pengawasan terhadap warga negara asing, pengawasan masih dilakukan dengan cara mengunjungi tempat atau perusahaan tempat warga negara asing tersebut, dalam mengatasi hambatan pengawasan Warga Negara Asing di MakassarKantor Imigrasi Makassar bekerja sama dengan instansi yang terkait seperti Kepolisian Daerah Republik Indonesia, Pemerintah Kabupaten dan Kota, Dinas Ketenagakerjaan dan Transmigrasi Kota Makassar dan Polisi Resort Kota Besar Makassar. Faktor Ekternal yaitu luasnya wilayah kerja Kantor Imigrasi Makassar yang meliputi 10 Kabupaten dan 1 Kotamadya

\section{DAFTAR PUSTAKA}

Abdullah Sjahriful. 1993. Memperkenalkan Hukum Keimgrasian. Jakarta. Penerbit : Ghalia Indonesia

APINDO.DPP DKI. 2003. Kumpulan SK Menteri Tenaga Kerja dan Transmigrasi Republik Indonesia. Bagian II. Sekertaris APINDO DKI.

Baharuddin Amyasi, 2009. Homo Homini Lupus (Manusia adalah serigala bagi yang lain. Blogkoe.com. Diakses pada Tanggal 16 Februari 2020

Bernard L. Tanya, 2011. Politik Hukum. Genta Publishing. Yoyakarta

Bernard.L.Tanya. 2011. Politik Hukum Agenda Kepentingan Bersama. YogYakarta. Penerbit : Gentha Publishing.

Charles Chistian.2015. Hukum Kemigrasian Bagi Orang Asing di Indonesia. Jakarta, Penerbit : Sinar Grafika

Edy, E., Hamka, H., \& Maldun, S. (2019). Implementasi Kebijakan Peraturan Presiden No 87 Tahun 2016 Tentang Satuan Tuagas Sapu Bersih Pungutan Liar. Jurnal Paradigma Administrasi Negara, 1(1), 32-37.

Imam Syaukani, 2004. Dasar-Dasar Politik Hukum. PT Radja Grafindo Persada. Jakarta

Jazim Hamidi dan Charles Christian,2016. Hukum Keimigrasian Bagi Orang Asing di Indonesia. Sinar Grafika. Jakarta. Cetakan kedua

Jazim Hamidi.2015. Hukum Keimigrasian bagi orang Asing di Indonesia.Jakarta Timur. Penerbit : Sinar Grafika

Keputusan Menteri Kehakiman RI Nomor M.01.IZ.01.10 Tahun 2005 Tentang Visa Kunjungan Saat Kedatangan.

Keputusan Menteri Kehakiman RI Nomor M.02.IZ.01.10 Tahun 1995 Tentang Visa Singgah. Visa Kunjungan. Visa Izin Tinggal Terbatas. Izin Masuk dan Izin Keimigrasian.

Keputusan Presiden Republik Indonesia Nomor 18 Tahun 2003 Tentang Bebas Visa Kunjungan Singkat (BVKS).

khairil Anwar. 2011. Pemberian Kitas bagi orang asing disponsori istri ditinjau dari perspektif hukum keimigrasian. Malang. Penerbit : Unbraw Malang
M.Iman Santoso. 2013. Perspektif Imigrasi Dalam Pembangunan Ekonomi dan Ketahanan Nasional. Jakarta. Penerbit : Universitas Indonesia.

Mirza Nasution, 2004. Negara dan Konstitusi. Bagian Hukum Tata Negara. Fakultas Hukum Universitas Sumatra Utara

Muhsan. 1997. Sistem Pengawasan terhadap Perbuatan Aparat Pemerintah dan peradilan tata usaha Negara di Indonesia. Yogyakarta. Penerbit : Liberty

Peraturan Pemerintah Nomor 32 Tahun 1994. Tentang Visa, Izin. Masuk. Dan Izin Keimigrasian.

Pusat Info Data Indonesia. 2006. Undang-undang Nomor 12 Tentang Kewarganegaraan Republik Indonesia. Jakarta, Pusat Info Data Indonesia.

Ridwan. 2006. Hukum Administrasi Negara. Jakarta. Penerbit : Raja Grafindo Persada

Ruslan Renggong. 2019. Hukum Pidana Khusus (edisi revisi). Jakarta. Prenada Media Group

Sihar Sihombing 2009. Hukum Imigrasi. Bandung. Penerbit : Nuansa Aulia.

Sihar Sihombing. Hukum Keimigrasian Dalam Hukum Indonesia. Bandung. Penerbit : Nuansa Aulia.

Sinar Grafika. 2000. Undang - undang Keimigrasian. Sinar Grafika Offset Cet . kedua.

Sinar Grafika. 2006. Undang - Undang Kekuasaan Kehakiman (UU No. 4 Tahun 2004). Jakarta. Penerbit : Sinar Grafika Offset, Kedua.

Sudikno Mertokusumo. 1993. Bab-bab tentang Penemuan Hukum. Bandung. Penerbit : Citra Aditya Bakti

Sunarti Hartono. 1994. Perspektif Pembangunan Hukum dalam Pembangunan Nasional Memasuki PJPT II. Penerbit : Majalah Hukum Nasional

Undang-Undang Nomor 06 Tahun 2011 tentang Keimigrasian. Jakarta. Penerbit : Nuansa Aulia. 